\title{
Sloveenia folkloristika suurmehe Niko Kureti elutööst
}

\author{
Helena Ložar-Podlogar, \\ Ingrid Slavec Gradišnik, Jurij Fikfak
}

Trsti (Triesti) linnas 24. aprillil 1906 sündinud Niko Kuret kolis koos perekonnaga hiljem oma emakoju Lažišesse, mis asub Sloveenia Styrias, et varjuda Esimese maailmasõja laastamistöö eest. Pärast keskkooli lõpetamist Celjes otsustas ta minna õppima prantsuse keelt ja võrdlevat kirjandust ning lõpetas ülikooli 1930. aastal. Seitse aastat hiljem, 1941. aastal sooritas ta kvalifikatsioonieksami ka itaalia keeles ja kirjanduses. Tehes uurimistööd keskaegse vaimuliku teatri kohta avastas ta rahvapärase teatri maailma, mis sütitas tema innukas loomuses teatriarmastuse. Ta hakkas välja andma sarja Ljudske igre (Rahvamängud), mille 28 köidet ilmusid ajavahemikus 1932-1939. Selles sarjas ilmusid ka N. Kureti olulisimad näitemängude mugandused (Lovrenc Marušiči (Romuald

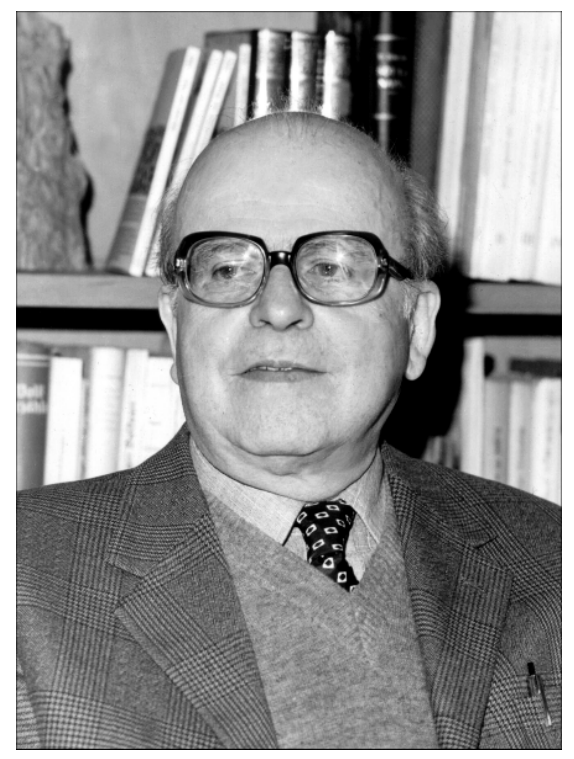
Štandreški; 1676-1748) Slovenski [Škofjeloš-

ki] pasijon ja Andrej “Drabosnjak” Šušteri (surn 1825) Igra o izgubljenem sinu, Božična igra ja Igra o Kristusovem trpljenju, aga ka Bela Krajinas peetud jüripäeva- ja pööripäevapidustuste mugandused) ilmusid selles sarjas. Aastatel 1934-1940 oli ta ainuisikuliselt ajalehe Ljudski oder (Rahvalava, 1934-1940) kujundaja, toimetaja ja väljaandja. Selles ajalehes ilmunud artiklid rahvapäraste näitemängude ja muu rahvapärase tegevuse kohta said rahvapärase teatri muganduste valdkonnas suunaandvaks.

N. Kureti algne otsus asuda tööle õpetajana osutus mitmete administratiivsete raskuste tõttu keeruliseks. Lühike ülevaade tema selle perioodi tegevustest oleks järgmine: mõnda aega tegi ta Kranj keskkoolis õpetajatööd, kuid vallandati 1929. aastal peaministriks saanud kindral Petar Živkovići diktatuuri ajal sellelt kohalt. Seejärel töötas ta kirjastuses Mohorjeva družba toimetajana, tegi kaastööd ühele raadiojaamale, teenis elatist prantsuse keele eraõpetaja ning prantsuse, saksa ja itaalia keele tõlgina, kirjutas populaarteaduslikke artikleid ning sai lõpuks Jugoslovanska knji-

http://haldjas.folklore.ee/tagused/nr34/kuret.pdf 
garna raamatukogusekretäriks. Pärast Teist maailmasõda, kui tal õnnestus õpetajatööd jätkata, leidis ta esmalt rakendust mitmes keskkoolis ning jätkas siis Riiklikus Turismi ja Teeninduse Kutsekoolis. Tema õpetajakarjäär lõppes 1954. aastal, kui ta sai töökoha Sloveenia Teaduste ja Kunstide Akadeemia alluvusse kuuluvas Sloveenia Etnoloogia Instituudis.

Pilk N. Kureti sõjaeelsele “mitteetnoloogilisele" loometööle loob mulje äärmiselt aktiivsest ja süsteemsest isikust, kelle sooviks oli populariseerida sloveenia rahvakultuuri - valdkond, millega ta tutvus oma arvukate tegevuste käigus - ja seda publitseerida. Tõenäoliselt oli see põhjuseks, miks ta otsustas kohe pärast sõda õppida ülikoolis ka "etnoloogiat koos etnograafiaga". Ta lõpetas oma õpingud 1947. aastal ja kaitses 1956. aastal doktoriväitekirja Zazibalne kolede na Slovenskem (Sloveenia hällilaulud).

Tunnetades tugevalt vajadust süstemaatiliselt organiseeritud teadustöö järele, visandas N. Kuret üksikasjaliku plaani sloveenia etnograafilise erialasõnastiku - ehk nagu ta ise seda nimetas - Sloveenia etnograafilise arhiivi koostamiseks, mille ta esitas akadeemia juhtkonnale. See oli Sloveenia Etnograafia Komisjoni sünnihetk (1947. aastal). Komisjon omakorda sai 1951. aastal Sloveenia Etnoloogia Instituudi rajamise baasiks.

Olles alates 1954. aastast instituudis täiskohaga tööl, asus N. Kuret kirglikult ja entusiastlikult tegema teadustööd. Ta oli väljaannete Glasnik Inštituta za slovensko narodopisje (Sloveenia Etnograafia Instituudi Bülletään, 1956-1957) ja Glasnik Slovenskega etnografskega društva (Sloveenia Etnograafia Seltsi Bülletään, alates 1957) kaastoimetaja, olles ühtlasi Sloveenia Etnograafia Seltsi (1969-1973) ja Jugoslaavia Folkloristide Seltsi (1970-1971) juhataja. Koos kolleegidega rajas ta institutsiooni Alpes orientales, mis kujutab endast Ida-Euroopa etnograafide nõukogu, ja algatas instituudi ajakirja Traditiones (1972) väljaandmise. Ta korraldas näitusi, oli initsiaatoriks etnograafilise filmi valdkonnas, pidas loenguid nii kodu- kui ka välismaal, korraldas instituudi välissuhteid, osales kodu- ja välismaistel konverentsidel, esindas rahvusvahelisel areenil sloveenia kultuuri, publitseerides artikleid välismaistes erialaväljaannetes, oli regulaarseks külaliseks kohalikes ja välismaistes raadiojaamades ning osales Sloveenias tulistes etnoloogiateemalistes aruteludes.

Aastatel 1951-1974 oli N. Kuret rahvusvahelise folkloristikabibliograafia Internationale volkskundliche Bibliographie esimene sloveenist toimetaja ja rahvusvahelise bibliograafilise ajakirja Demos kohalik toimetaja.

On praktiliselt võimatu süstematiseerida N. Kureti äärmiselt mahukat ja mitmekülgset teadlasetööd. Tema etnoloogiaalane toodang ulatub umbes neljasaja bibliograafilise kirjeni, millest sada on originaalartiklid. Lisaks reale populaarteaduslikele artiklitele on ta enam kui kahekümne raamatu autor.

Suuresti N. Kureti panus oli Carinthia piirkonnast pärit kirjaniku Andrej "Drabosnjak" Šušteri näitemängude esmakordne mugandamine, samuti lembržanite (teatud rahvakild) kohta käivate humoorikate lugude publitseerimine. Ta kirjutas raamatukese mänguasjade ja mängude kohta (Igra in igrača), mis ilmus sarjas Veselja dom (Lõbus kodu, perekondlike ajaviitemängude kogu) 1942. aastal, ja andis välja hindamatu kogu peomänge pealkirjaga Vesele ure (Lõbusad tunnid, lühendatud versioon 1969). Ta käsitles sloveenia mänge Euroopa kontekstis - Ljubljanska igra o paradižu in njen evropski okvir (Ljubljana paradiisimäng ja selle Euroopa kontekst, 1958), Ziljs- 
ko štehvanje (Štehvanje Gaili orus, 1963). 1959. aastal kirjutas ta stsenaariumi filmile, mis käsitles štehvanje traditsiooni Gaili orus ja juhendas filmivõtteid. Samuti algatas ta mitmete etnoloogiliste filmide väntamise ja oli ise neist paljude stsenaariumi autor.

N. Kureti süstemaatiline uurimistöö aastaringiga seonduva kombestiku vallas on leidnud väljundi mitmetes monograafiates, nende hulgas Praznično leto Slovencev (Sloveenide pidulik aasta; 1965-1970, täiendatud trükk 1989, lühendatud saksakeelne trükk Das festliche Jahr der Slowenen 1996) ning Jaslice na Slovenskem (Jõuluaegsed Kristuse sünnistseenide kujutamised, 1981). Monumentaalne teos on ka tema monograafia sloveenia karnevalimaskidest Maske slovenskih pokrajin (Sloveenia piirkondade maskid, 1984), mis põhineb N. Kureti korduvatel ulatuslikel välitöödel, real teoreetilise taustaga käsitlustel ja mahuka, kõikides Sloveenia piirkondades läbi viidud küsitluse analüüsil. N. Kuret kasutas võrdleva etnograafia meetodeid ja töötas lisaks läbi nii Sloveenia kui ka välismaiseid allikaid ja erialakirjandust, et olla pädev vaatlema sloveenia karnevalimaske rahvusvahelises kontekstis. See oli teema, mis pakkus talle paljudeks aastateks sügavat huvi, võimalik, et sellest ajast peale, kui ta hakkas uurima rahvapärast teatrit. Tegelemisest rahvapärase teatri teemaga sündisid vähemalt kaks põhjapaneva tähtsusega raamatut: Duhovna drama (Vaimulik draama, 1981) ja Sloveenia traditsiooniliste jõululauludega seotud kombeid kirjeldav Slovenska koledniška dramatika (1986).

Niko Kureti arvukad publikatsioonid, uurimisprojektid ja tõlgendused on saanud põhjaks ja kohati ka juhendiks rea kommete ja tavade tänapäevastele rekonstruktsioonidele. Tema uurimistöö aitas äratada inimestes taas huvi karnevalifiguuride vastu: Cerkno piirkonna laufarji, Dobrepolje piirkonna mačkare, teatud määral ka škoromati Brkini piirkonnas, kui nimetame vaid mõnda neist. N. Kureti püüded rekonstrueerida ja taaselustada rahvakultuuri leidsid väljundi tema varasemates rahvapärase teatri draamade mugandustes, mida ta populariseeris ka raadioprogrammide kaudu, ning - kuigi kaudsemal moel - kaasaegse rahvakultuuri käsiraamatutes, nagu näiteks Pregled slovenskega ustnega slovstva (Uurimus sloveenia rahvaluulest, 1950), Obnovitev starih in uvedba novih zgodovinsko-folklornih prireditev na območju Slovenske Istre s posebnim ozirom na Piran-Portorož (Vanade ajalooliste folkloorisündmuste rekonstrueerimine ja uute juurutamine Sloveenia Istra piirkonnas eelkõige Pirani ja Portoroži näitel, 1960) ja Turističèna etnografija (Etnograafia turistidele, 1961).

N. Kuret oli mitmeköitelise sarja Slovensko Štajersko pred marčno revolucijo 1848 (Sloveenia Steiermark enne 1848. aasta märtsirevolutsiooni) toimetaja. Seda sarja tuntakse ka nimetuse Göthova serija (Göthi sari) all ja tegemist on mahuka topograafiliste andmete koguga, mis koguti spetsiaalse küsimustiku põhjal (autoriteks peahertsog Johann Austriast (1818) ja Georg Göth (1848)). N. Kuret sai Grazi Provintsiarhiivist vajalikud koopiad, klassifitseeris kogu materjali, koostas (kakskeelse) toponüümilise kataloogi ja andis välja neli esimest köidet (kuni j-täheni).

Olulisimad Niko Kureti võõrkeelsed artiklid tõlgiti ja pandi kokku kogumikuks Opuscula selecta. Poglavja iz ljudske culture (Opuscula selecta. Peatükke rahvakultuurist, 1996). See kogumik ilmus pärast akadeemiku surma. Teine postuumselt ilmunud teos on raamat advendikombestikust pealkirjaga Marijo nosijo (Neitsi Maarja kandmine; 1997).

Et N. Kuret oli juba mitukümmend aastat tagasi (veel Sloveenia Etnograafia Komisjoni perioodil) kavatsenud välja anda sloveenia etnograafia sõnastiku, koostas ta 
selleks märksõnade indeksi mustandi. Aastaid hiljem õnnestus tal veel näha vähemalt oma suure projekti formaalset (1989) ja tegelikku (1991) algust. Leksikon Slovenski etnološki leksikon (Sloveenia etnoloogialeksikon) ilmus 2004. aastal. N. Kuret pani kirja peaaegu tuhat märksõna, millest ainuüksi kaheksasada seostusid aastatsükli kombestikuga, ja umbes kolmesaja märksõna kohta kirjutas ta ise ka seletuse.

Olles saanud Pitrè autasu kahekordseks laureaadiks (Premio Pitrè, Palermo, Itaalia 1955. ja 1971. aastal), omistati N. Kuretile lisaks sellele veel Herderi elutööpreemia (Herder-Preis, Viin, Austria, 1966). Tema tööd on korduvalt kõrgelt tunnustatud: 1972. aastal sai temast Boris Kidriči Fondi laureaat, mis oli tollal kõrgeim võimalik autasu teaduslike teenete eest, ka oli ta esimene Murko autasu laureaat - selle autasu andis talle Sloveenia Etnoloogia Selts 1988. aastal. Ta oli Rahvusvahelise Etnoloogia ja Folkloristika Seltsi (Société Internationale d'Ethnologie et de Folklore) asutajaliige. Alates 1968. aastast oli ta Belgia Kuningliku Folkloorikomisjoni auliige. 1989. aastal sai temast lõpuks Sloveenia Teaduste ja Kunstide Akadeemia toetajaliige, kaks aastat hiljem akadeemia täisliige. 1993. aasta novembris valiti ta Euroopa Teaduste ja Kunstide Akadeemia (Salzburg, Austria) liikmeks.

Niko Kuret suri 25. jaanuaril 1995 Ljubljanas.

\section{Summary}

\section{On Niko Kuret, grand-old-man of Slovenian Folklore Studies, and His Life Career}

Slovenian academician Niko Kuret (Trst/Triest, April 24, 1906 - Ljubljana, January 25,1995 ) not only laid the foundation for the ethnological institute and steadily developed it as an institution, but also contributed valuable research in the fields of ethnology and folklore studies in which his successors continue to discover scholarly and professional challenges. Overview of the lasting and meaningful life work of Niko Kuret by Slovenian folklorists Helena Ložar-Podlogar, Ingrid Slavec Gradišnik and Jurij Fikfak. 